\title{
a infância no cinema de abbas kiarostami
}

\author{
darian soheil rahnamaye rabbani ${ }^{1}$ \\ universidade de são paulo, brasil \\ julio groppa aquino ${ }^{2}$ \\ universidade de são paulo, brasil \\ orcid id: https:/ / orcid.org/0000-0002-7912-9303
}

resumo

O presente artigo devota-se a descrever e analisar o endereçamento à infância em algumas obras cinematográficas de Abbas Kiarostami. Para tanto, a argumentação voltase inicialmente à contextualização da Revolução Iraniana de 1979, responsável pelo fim do regime monárquico do Xá Reza Pahlavi, que tinha a laicidade e a modernidade como motes, e pelo o início da República Islâmica do Irã, centrada na figura do Aiatolá Khomeini e apoiada na tradição islâmica. Nesse cenário, destaca-se o papel do Instituto para o Desenvolvimento Cultural da Criança e do Adolescente, referido como Kanun. Fundado com o propósito de criar obras de cunho educativo durante o regime do Xá, o Kanun foi de fundamental importância para a produção artístico-cultural do país, tanto antes quanto depois da Revolução. Especialmente, seu departamento de cinema, no qual vários cineastas iniciaram suas carreiras (entre eles, Kiarostami, o primeiro diretor do departamento), é considerado o berço do movimento reconhecido como o Novo Cinema Iraniano. Assim, o presente trabalho debruça-se sobre as narrativas acerca da infância presentes em tais filmes, considerando a ambiência pós-revolucionária e, presumidamente, a tarefa de construção de um novo sujeito histórico a partir de um marco outro para a infância. Mais especificamente, o trabalho oferece uma análise articulada de seis obras cinematográficas de Kiarostami produzidas no período de 1970 a 1989. Em todas elas é possível testemunhar uma interrogação sobre a posição das crianças naquele contexto societário. Após uma discussão sobre o uso de filmes como fonte investigativa, apresentam-se três movimentos argumentativos identificados em tais obras, intitulados respectivamente: a criança à margem da sociedade; a criança no centro da sociedade; e a criança da revolução. Ao final das discussões, propõe-se que o cinema de Kiarostami consistiu em um ponto de inflexão das modalidades de veridicçãosubjetivação ali correntes. Tratava-se, assim, em um tipo peculiar de exercício éticopolítico, por meio de uma experimentação narrativa que se valia do universo infantil como ocasião de prospecção dos ideais do processo revolucionário.

palavras-chave: infância; cinema; abbas kiarostami; revolução iraniana.

\section{la infancia en el cinema de abbas kiarostami}

\section{resumen}

Este artículo se dedica a describir y analizar el acercamiento a la infancia en algunas obras cinematográficas de Abbas Kiarostami. Para eso, la argumentación se volvió

\footnotetext{
${ }^{1}$ E-mail: dariansrr@gmail.com

2 E-mail: roppaq@usp.br.

childhood E philosophy, rio de janeiro, v. 15, jan. 2019, pp. 01 - 28
}

issn 1984-5987 
a infância no cinema de abbas kiarostami

inicialmente a la contextualización de la Revolución Iraní de 1979, responsable del fin del régimen monárquico del Sha Reza Pahlavi, que tenía la laicidad y la modernidad como motes, y del inicio de la República Islámica de Irán, centrada en la figura del ayatolá Jomeini y apoyada en la tradición islámica. En ese escenario, se destaca el papel del Instituto para el Desarrollo Cultural del Niño y del Adolescente, referido como Kanun. Fundado con el propósito de crear obras de cuño educativo durante el régimen del Sha, el Kanun fue de fundamental importancia para la producción artístico-cultural del país, tanto antes como después de la Revolución. Especialmente, su departamento de cine, en el que varios cineastas iniciaron sus carreras (entre ellos, Kiarostami, el primer director del departamento), es considerado la cuna del movimiento reconocido como el Nuevo Cine Iraní. Así, este trabajo se centra en las narrativas acerca de la infancia presentes en tales películas, considerando el ambiente post-revolucionario y, presumiblemente, la tarea de construir un nuevo sujeto histórico desde otro marco para la infancia. Más específicamente, el trabajo ofrece un análisis articulado de seis obras cinematográficas de Kiarostami producidas en el período de 1970 a 1989. En todas ellas es posible testificar una interrogación sobre la posición de los niños en ese contexto societario. Tras una discusión sobre el uso de películas como fuente investigativa, se presentan tres movimientos argumentativos identificados en tales obras, titulados respectivamente: el niño al margen de la sociedad; el niño en el centro de la sociedad; y el niño de la revolución. Al final de las discusiones, se propone que el cine de Kiarostami consiste en un punto de inflexión de las modalidades de veridicción- subjetivación allí corrientes. Se trataba, así, de un tipo peculiar de ejercicio ético-político, por medio de una experimentación narrativa que se valía del universo infantil como ocasión de prospección de los ideales del proceso revolucionario.

palabras clave: infancia; cinema; abbas kiarostami; revolución iraní.

\section{childhood in abbas kiarostami's cinema}

abstract

This article analyzes the theme of childhood in the films of Abbas Kiarostami in the context of the 1979 Iranian Revolution, which toppled the secular, modernizing regime of Shah Reza Pahlavi and ended in the establishment of Islamic Republic of Iran under the leadership of Ayatollah Khomeini. It pays special attention to the Institute for the Cultural Development of Children and Adolescents, or Kanun. Founded during the Shah's regime with the objective of creating educational materials, Kanun played an important role in Iran's artistic-cultural production, both before and after the Revolution. Its cinema department, where several filmmakers started their careers (among them, Kiarostami, the first director of the department), became known as the birthplace of New Iranian Cinema. This article examines how six of Kiarostami's films, produced between 1970 and 1989, discuss the position of children in Iranian society. In particular, it considers the changes wrought by the Revolution and the founding of a new historical 


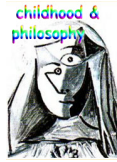

subject based on a different framework for childhood. After a discussion of the use of films as a source for research, three framings of childhood in Kiarostami are presented: the child on the margins of society, the child at the center of society, and the child of the Revolution. The article closes by arguing that through narrative experimentation that uses childhood as a vehicle to explore the ideals of the revolutionary process, Kiarostami's cinema serves as an inflection point for the modalities of veridiction and subjectivation and a peculiar type of ethical-political struggle.

keywords: childhood; cinema, abbas kiarostami; iranian revolution. 
a infância no cinema de abbas kiarostami

a infância no cinema de abbas kiarostami

Em 1979, o Irã viveu uma revolução responsável por uma mudança radical de governo no país, culminando no fim do regime monárquico do Xá Reza Pahlavi e na instalação da República Islâmica do Irã, centrada na figura do Aiatolá Khomeini. Os eventos que marcaram o levante popular iniciaram-se em 1977, intensificando-se em 1978, até atingirem seu apogeu no início de 1979, quando foi convocado um plebiscito nacional pela instauração da República Islâmica e a vitória do Aiatolá foi esmagadora (COGGIOLA, 2008).

Tal mudança na forma de governo baliza a organização política do país até os dias atuais, tendo se transmutado de uma monarquia que, entre outros motes, buscava a laicidade e a modernização, para um governo lastreado nos valores da tradição islâmica. A partir disso, é possível traçar dois horizontes que possibilitaram a insurreição: primeiro, um descontentamento político e econômico que permeava as diferentes camadas sociais iranianas; segundo, uma identificação do levante à figura de Khomeini. Relembre-se, no entanto, que, à época, existiam múltiplas forças em disputa pelos ideais revolucionários, tanto internas como externas ao próprio Islã. No entanto, os gritos de saudação ao Aiatolá - que nos primeiros dias de fevereiro de 1979 regressou de seu exílio na França - ultrapassaram a população islâmica e se espalharam entre aqueles que não eram seguidores do mesmo credo.

Com vistas a compor uma visão geral dos eventos que ali tomaram lugar, valemo-nos sumariamente dos escritos de Michel Foucault sobre o tema, quem, a convite do editor do jornal italiano Corriere della Serra, visitou o Irã por duas vezes em 1978. Dos acontecimentos lá testemunhados derivaram artigos, cartas abertas e entrevistas de Foucault, totalizando menos de duas dezenas de textos, todos eles publicados em jornais (no caso, Corriere della Sera, Le nouvel Observateur, Le matin e Le monde) entre 1978 e 1979.

Foucault entrevistou estudantes, trabalhadores, lideranças políticas e religiosas, militantes, velhos e jovens. E "a todos que encontra Foucault faz a mesma 
pergunta: ‘O que você quer?'. E invariavelmente obtém a mesma resposta: 'Um governo islâmico'" (ERIBON, 1990, p. 264). Em seus escritos sobre o tema, o pensador constantemente evocou o papel do Islã na Revolução a operar uma relação intrínseca, naquele contexto, entre política e religião, em um diapasão contrário àquele do Ocidente moderno.

Em seu primeiro artigo em francês - até então os outros artigos haviam sido apresentados ao público na língua italiana - intitulado Com o que sonham os iranianos?, Foucault (2013a) relata que o que lhe impressionou naquela proposta de governo era menos sua condição de ideal do que sua forma de vontade política. Sobre esta, Foucault relembra que, nos primórdios da história, o Estado fora inventado na Pérsia e sua guarda confiada ao Islã, uma vez que seus administradores compuseram o califado. No entanto, a mesma religião, mais tarde, subsidiaria a insurreição contra o poder de Estado, no caso da revolta contra o Xá. Tendo em vista tal descontinuidade histórica, a demanda por um governo islâmico significaria, indaga Foucault (2013a, p. 236), "uma reconciliação, uma contradição ou o limiar de uma novidade?".

E ele próprio esboça uma resposta, a reboque dos testemunhos proferidos:

Precisamos mudar, certamente, de regime e livrar-nos desse homem [Pahlavi], precisamos mudar esse pessoal corrompido, precisamos mudar tudo no país, a organização política, o sistema econômico, a política estrangeira. Mas sobretudo precisamos mudar a nós mesmos. É preciso que nossa maneira de ser e nossa relação com os outros, as coisas, a eternidade, Deus etc. sejam completamente mudadas e só haverá a revolução real na condição dessa mudança radical em nossa experiência. Creio que foi aí que o Islã representou um papel. (FOUCAULT, 2013b, p. 264)

Se, na primeira mirada de Foucault, destaca-se a relação entre o Islã e o Estado, no segundo momento desponta o vínculo que se estabelece entre religião e sujeito. Daí o Islã como uma força a sustentar a intersecção entre o Estado e o sujeito, esse novo protagonista histórico da contemporaneidade.

A Revolução Iraniana despontou como reação da população não apenas às estruturas políticas e econômicas do país, mas também às ações artístico-culturais, as quais eram reputadas por grande parcela dos iranianos como uma investida do imperialismo ocidental. Tratava-se então de incitar práticas que condissessem com os valores locais. Daí o papel do Instituto para o Desenvolvimento Cultural da Criança e childhood \& philosophy, rio de janeiro, v. 15, jan. 2018, pp. 01- 28 
a infância no cinema de abbas kiarostami

do Adolescente (Kanun-e Parvaresh-e Fekri-ye Kudakan va Nowjavanan), doravante referido como Kanun, o qual guarda um interesse analítico ímpar para que se possa contextualizar o horizonte da Revolução naquele país. Fundado com a intenção de criar obras de cunho educativo durante o regime do Xá e mantido após a proclamação da República Islâmica, a instituição foi de fundamental importância para a produção cultural no Irã, uma vez que ali vários cineastas iniciaram suas carreiras, entre eles Bahram Beizaie, Amir Naderi, Reza Alamzadeh e, sobretudo, Abbas Kiarostami.

O Kanun fora fundado por Fahra Pahlavi, esposa do Xá, em meio a uma série de políticas de fomento à cultura. A instituição foi responsável por produções em diversos âmbitos, da literatura às artes gráficas, tendo a infância como eixo central. Entre os anos de 1969 e 1970, a convite de Ebrahim Forouzesh, diretor do Kanun, Kiarostami inaugurou e passou a dirigir o departamento de cinema do Instituto. Logo o departamento se tornaria o mais produtivo do Kanun, além de um marco histórico na produção cinematográfica do Irã (MELEIRO, 2006).

Kiarostami (2013) relata que, até ingressar no Kanun, trabalhava como diretor de filmes publicitários e que nunca havia feito um vídeo que não fosse para anúncios publicitários. O antigo diretor do Instituto assistiu a uma peça televisionada criada por Kiarostami e decidiu convidá-lo para fundar o departamento. Sobre seu ingresso no Instituto, o cineasta afirmou: “Eu não sabia nada sobre infância e nem da profissão de diretor de cinema, mas, como todos os outros, comecei às cegas. Assim, tornei-me diretor de filmes para crianças devido a uma coincidência banal" (KIAROSTAMI, 2013, p. 200).

Até meados dos anos 1960, as salas de cinema iranianas ocupavam-se de filmes produzidos em Hollywood e de produções indianas inspiradas nas norteamericanas. Os trabalhos cinematográficos iranianos seguiam os mesmos moldes, o que mais tarde seria condenado pelas lideranças islâmicas como uma forma de colonização cultural. Durante os dias mais conturbados que antecederam a implementação do novo regime, diversos cinemas e teatros foram queimados pela 
população, por serem considerados símbolos da cultura ocidental e da dinastia Pahlavi (TAPPER, 2002).

Os filmes produzidos no Kanun constituem, assim, um marco do início de um movimento que será referido por alguns teóricos como o Novo Cinema Iraniano. Este tinha como característica comum a insatisfação dos cineastas com a produção cinematográfica nacional de até então, pois acreditava-se que ela, ao mimetizar as estruturas do cinema norte-americano, embasava-se em uma lógica que refratava a cultura do país. Tal ideia, claro está, alinhava-se imediatamente aos ideais do regime pós-revolucionário. Prova disso é um pronunciamento de Khomeini (apud TAPPER, 2002, p. 6, tradução nossa): “O cinema é uma manifestação cultural e deve ser posto a serviço do homem e de sua educação". Daí, talvez, o fato de o Kanun continuar a ser uma instituição mantida pelo regime desde a Revolução até os dias atuais.

As produções cinematográficas de Kiarostami no Kanun apresentam-se das mais diversas formas: curtas e longas metragem, ficções, documentários, além de filmes didáticos. Mediante tal diversidade temática e de forma, apenas uma constância: a infância, na maior parte das vezes como objeto narrativo, mas também, em alguns casos, como público destinatário. "Embora o objetivo principal da Kanun fosse produzir filmes para crianças, a maior parte dos filmes era feita por intelectuais e claramente nem todos os filmes eram para crianças, a maior parte deles eram sobre crianças" (MELEIRO, 2006, p. 42, grifos da autora).

Com efeito, é possível testemunhar em todos os filmes de Kiarostami no Kanun uma interrogação sobre a criança e sua posição na sociedade. Entendendo a revolução como um corte histórico radical ali operado, o presente trabalho debruçase as narrativas sobre a infância presentes em algumas obras cinematográficas selecionadas de Kiarostami, tendo como horizonte a ambiência pós-revolucionária e, presumidamente, a tarefa de construção de um novo sujeito histórico a partir de uma infância outra. 
a infância no cinema de abbas kiarostami

\section{o cinema como fonte investigativa}

Em uma entrevista à revista Cahiers du Cinéma, Kiarostami (apud BERNARDET, 2004, p. 160) propõe o seguinte: “Para mim, a realidade filmada não é mais real. Portanto, trucagens e a maquinaria permitem simplesmente voltar à realidade que somos em geral incapazes de filmar". Para o iraniano, as gravações esvaziariam o acontecimento de uma suposta realidade, fazendo com que o produto final converta-se em ficção. Em outra entrevista, apresenta ideia parecida:

Seja documentário ou ficção, o todo é sempre uma grande mentira que contamos. Nossa arte consiste em contá-la de modo que acreditem nela. Se uma parte é documentário e outra parte é reconstituição, isso diz respeito ao método de trabalho, não ao público. O mais importante é alinhar uma série de mentiras de modo a alcançar uma verdade maior. Mentiras irreais, mas de algum modo verdadeiras (KIAROSTAMI, 2013, p. 87).

Se compreendido dessa maneira, o cinema torna-se uma fonte inesgotável de acesso aos jogos de veridicção em voga em determinado momento histórico, entendidos por Foucault (1984, p. 12) como os “[...] jogos entre o verdadeiro e o falso, através dos quais o ser se constitui historicamente como experiência, isto é, como podendo e devendo ser pensado". No entanto, operar com filmes como objetos investigativos requer certas precauções procedimentais.

Por exemplo, Fabiana Marcello e Rosa Fischer (2011, p. 507, grifos das autoras) ponderam que "não há nada por trás dos gestos do cinema", apostando na inexistência de qualquer suposta verdade essencial revelada no trabalho cinematográfico. Logo, operar com o cinema como objeto de pesquisa deveria consistir em um exercício do olhar.

As autoras propõem que a obra cinematográfica seja vista como matéria livre de qualquer forma de transcendência ou intencionalidade. A imagem não poderia, portanto, ser reduzida a interpretações, pois estas são inesgotáveis; e isso não por incapacidade daquele que olha, mas porque ela sempre abre espaço para novas leituras e outras descrições, impossibilitando o plano narrativo abarcar todos os sentidos do visual. Incompatibilidade entre linguagem e imagem, portanto.

Elí Fabris (2008, p. 120), outra pesquisadora da díade cinema-educação, concebe os filmes "como produções datadas e localizadas, produzidos na cultura, 
criando sentidos que a alimentam, ampliando, suprimindo e/ou transformando significados". Procurando se distanciar de análises que tomam as obras cinematográficas como narrativas fiéis e definitivas, a autora prefere uma leitura que leve em conta o contexto cultural no qual o filme circula e produz seus efeitos. Em outra passagem, declara: "Tomei o cinema como um produto criado culturalmente que traz as marcas, as inscrições das culturas na sua forma de expressão, nas representações que produz" (FABRIS, 2008, p. 126).

Na visão de Marcello e Fischer, há uma incompatibilidade entre imagem e linguagem, culminando na impossibilidade de a primeira representar algo maior. Já, para Fabris (2008), a análise de dada obra cinematográfica orienta-se segundo um duplo movimento: ela é produto e produtora de determinada cultura. E, para ser compreendida, ela exige que tenhamos em mente as características desse mesmo tempo-espaço.

Mediante tal cenário, são mais que oportunas as ideias de Georges DidiHuberman em seu texto Cascas (2013), segundo as quais supor a existência de uma suposta substância para além da superfície não passaria de metafísica. Ao contrário, trata-se de pensar a superfície como um produto direto, tal como uma casca que se separa de uma árvore. Diz ele: “A casca não é menos verdadeira que o tronco. É inclusive pela casca que a árvore, se me atrevo a dizer, se exprime. Em todo caso apresenta-se a nós" (DIDI-HUBERMAN, 2013, p. 132, grifos nossos). Aqui, no trato com as imagens, a ideia de representação dá lugar à de apresentação.

Já em Quando as imagens tocam o real, Didi-Huberman (2012) sugere que a imagem não existe sem a imaginação, mas que isso não implica que ela seja produto de desrealização. Ao contrário, a imaginação comportaria a "capacidade de realização, sua intrínseca potência de realismo" (DIDI-HUBERMAN, 2012, p. 208, grifos do autor). Portanto, assumir que a imagem, como produto da imaginação, seria desprovida de um caráter de realidade consistiria em um equívoco, tal como o seria pensar que uma fotografia exibiria a verdade da realidade que retrata. $\mathrm{O}$ paradoxo, portanto, refere-se ao fato de que a imagem não seria real nem irreal. A 
a infância no cinema de abbas kiarostami

incompatibilidade, aqui, talvez seja resultante justamente da tentativa de situar a imagem (ou, em nosso caso, os filmes) nas dicotomias real/irreal, verdade/ficção etc.

No mesmo texto, Didi-Huberman (2012, p. 210-211) afirma:

Cada vez que tentamos construir uma interpretação histórica - ou uma "arqueologia" no sentido de Michel Foucault -, devemos ter cuidado de não identificar o arquivo do qual dispomos, por muito proliferante que seja, com os feitos e gestos de um mundo do qual não nos entrega mais que alguns vestígios. O próprio do arquivo é a lacuna, sua natureza lacunar. Mas, frequentemente, as lacunas são resultado de censuras deliberadas ou inconscientes, de destruições, de agressões, de autos de fé. O arquivo é cinza, não só pelo tempo que passa, como pelas cinzas de tudo aquilo que o rodeava e que ardeu.

As imagens - no caso deste estudo, os filmes de Kiarostami sobre a infância no Irã - são por nós tomadas como arquivo, no sentido que lhe atribui Foucault (2014, p. 52): “A massa das coisas ditas em uma cultura, conservadas, valorizadas, reutilizadas, repetidas e transformadas. Em resumo, toda essa massa verbal que foi fabricada pelos homens". Mais especificamente, trata-se de substratos de uma matéria discursiva que, em seu tempo, encontrava-se em estado incandescente, mas que agora chega a nós na forma de cinzas. Em suma, "o arquivo como poeira do tempo" (AUTOR, 2018, p. 48).

Sendo assim, seja um curta-metragem com atores repetindo falas definidas por um roteiro, seja um longa-metragem gravado em uma escola documentando o diálogo entre um aluno e o diretor da instituição, ambos portariam, a rigor, o mesmo valor documental, uma vez que consistem em vestígios de um tempo outro que se atualiza aos olhos de quem deles se reapropria no presente. Trata-se de narrativas tão reais quanto imaginadas - que apontam, no caso do presente estudo, não para aquilo que teria sido a infância, ipso facto, no Irã dos anos 1970 e 1980, mas para o que pôde ser redito/revisto sobre ela aos olhos dos contemporâneos. Circulação discursiva, portanto. O cinema, em suma, como um exercício performador das verdades às quais alude e, no mesmo golpe, atualiza. 


\section{três matizes da infância no cinema de kiarostami}

Foram selecionadas seis obras cinematográficas para o trabalho analítico, tendo como critério o fato de que todas elas deveriam ter sido dirigidas por Kiarostami e produzidas pelo Kanun, bem como que a infância fosse seu objeto ou destinatário. Os filmes escolhidos distribuem-se no arco temporal de exatas duas décadas. São eles:

- O pão e o beco (Nan va kuche). 11 min. 1970.

- Duas soluções para um problema (Do rah-e hal baray-e yek mas'ale). 5 min. 1975.

- Caso 1, Caso 2 (Ghaziye shekl-e avval, Ghaziye shekl-e dovvom). 53 min. 1979.

- Os alunos do primeiro ano (Avvaliha). 79 min. 1985.

- Onde fica a casa do meu amigo? (Khane-ye dust kojast?). 83 min. 1987.

- Lição de casa (Mashq-e shab). 86 min. 1989.

Cabe esclarecer que todos os filmes foram assistidos na língua original: o farsi. Assim, as traduções impuseram-se como um problema. Nos casos em que existia uma legenda oficial em português, esta foi a fonte primária; em outros casos, fez-se a tradução das legendas em inglês. Quanto às traduções não oficiais, verificou-se o sentido original das formulações originais em farsi.

O crivo analítico do material deu-se segundo três patamares articulados. A saber: a criança à margem da sociedade; a criança ao centro da sociedade; e a criança da revolução.

\section{1. a criança à margem da sociedade}

Onde fica a casa do meu amigo? inicia-se em uma sala de aula com um professor brigando com o pequeno Mohamad Reza Nematzadeh, pois este fez a lição de casa em uma folha avulsa em vez de utilizar o caderno. O professor, incomodado com a recorrência da situação, informa que, se aquilo se repetisse, ele o expulsaria da escola. Na saída, o menino brinca com seu amigo Ahmad, antes de irem embora. Em casa, ao iniciar a tarefa, Ahmad se dá conta de que trouxe o caderno de Nematzadeh por engano e se desespera, pois sabe que, sem o caderno, o amigo será punido. O menino 
a infância no cinema de abbas kiarostami

pede à mãe que o deixe ir à casa do amigo para devolver o caderno, mas ela não lhe dá atenção e pede ao filho que vá comprar pão. O menino aproveita a situação para ir ao vilarejo vizinho, onde o amigo mora.

Onde fica a casa do meu amigo? foi o primeiro filme de Kiarostami a ser premiado em um festival ocidental, sendo considerado pela crítica uma importante obra do cinema iraniano. Ao discorrer sobre o processo de escolha dos atores, Kiarostami (2013, p. 222) destaca: “Quando saí à procura do protagonista, sabia que deveria ter uma fisionomia preocupada e que essa inquietude deveria refletir-se também em seu olhar". A angústia e a aflição de Ahmad são constantes no filme. Sua jornada para devolver o caderno de seu amigo é um fardo para a criança, que se encontra naquela situação por engano; no entanto, se falhar, as consequências recairão sobre o colega. Devolver o caderno torna-se uma obrigação moral.

A comunicação quase inexistente do protagonista com o mundo adulto torna a tarefa, que em princípio parece simples, deveras complexa. Ao longo da narrativa, Ahmad, ao pedir informações aos adultos, é ignorado; quando não, são confusas. As poucas orientações que o garoto consegue são provenientes de outras crianças que encontra ao longo do caminho; os únicos que param para lhe escutar, por sinal.

Em determinado momento, Ahmad encontra seu avô, que o interroga sobre onde havia estado; o menino responde que fora comprar pão. O avô insiste dizendo que não perguntou o que ele estava fazendo, mas onde estava. Silêncio. E completa perguntando o que o garoto fazia no vilarejo vizinho, ao que a criança responde que tentava devolver o caderno do amigo. O avô, então, pede ao menino que vá buscar seu cigarro que deixou em casa. O pequeno explica que está com pressa, mas o adulto insiste. Assim que sai para cumprir o que o avô lhe ordenou, um homem sentado ao lado do idoso the oferece um cigarro, mas ele recusa, pois tem seus cigarros consigo. Surpreso, o homem interroga sobre os motivos de ter exigido aquilo do neto, ao que o avô responde:

Meu objetivo não eram os cigarros, quero que esse menino se eduque para que amanhã seja um homem de bem. Quando eu era pequeno, a cada quinze dias meu pai me dava umas moedas e umas palmadas. Algumas vezes, propositalmente, esquecia de me dar o dinheiro, mas nunca esquecia de me 
dar umas boas palmadas, para eu crescesse como um homem de bem. Eu percebi que meu neto veio aqui e eu repeti três vezes a minha pergunta e mesmo assim ele não me deu atenção. [...] Devemos educá-los de modo que seja suficiente dizer-lhes as coisas apenas uma vez.

O adulto insiste na importância de os mais novos escutarem os mais velhos, afirmando que é preciso ensinar-lhes disciplina e obediência. Sem os cigarros, Ahmad volta até o avô. No caminho, depara com o grupo de homens engajados em uma negociação; um deles fabricava portas e tentava convencer os outros a comprá-las. Ao ver o caderno na mão de Ahmad, o artesão pede uma folha de papel, e o garoto explica que não lhe pode dar, pois o caderno é de seu amigo Mohamad. O homem insiste, dizendo que pouco se importa com isso. $\mathrm{O}$ garoto insiste que o caderno não é seu, e que, se arrancarem uma folha, o professor irá repreender seu amigo. $\mathrm{O}$ mais velho insiste, e o garoto também. Por fim, o comerciante diz: "Escute os mais velhos", e toma o caderno da mão do garoto.

Já o curta-metragem $O$ pão e o beco apresenta uma criança aparentando ter em torno de seis anos que, no caminho de volta para casa, é surpreendida por um cão. Com medo do animal, o pequeno encontra-se impedido de regressar ao seu lar. Ao longo da narrativa, três adultos passam pelo caminho: um homem montado em um burro, outro em uma bicicleta e um velho caminhando. Cada um cruza a viela onde se encontra o garoto parado, que olha para cada um na esperança de socorro, mas é sempre ignorado. Os dois primeiros vêm com velocidade e, talvez por isso, sequer notam a presença do garoto. $\mathrm{O}$ idoso, no entanto, caminha lentamente e tampouco olha para o garoto, que tenta segui-lo, mas volta para trás quando o velho toma outro rumo. O menino decide passar correndo pelo beco, mas logo o cão late e avança agressivamente. Ele então arremessa um pedaço de pão, que o cachorro rapidamente abocanha, acalmando-se. O pequeno consegue então atravessar o beco, e o cachorro o segue. Ao chegar em casa, o menino entra, e o animal faz menção de entrar junto, mas uma mulher o espanta e fecha a porta violentamente. Ganindo, o cão se deita ao pé da porta. E assim se encerra o curta-metragem.

Aqui, como em Onde Fica a Casa do meu amigo?, as filmagens mostram extensos quadros de close-up no rosto dos protagonistas, revelando sua angústia em childhood E philosophy, rio de janeiro, v. 15, jan. 2018, pp. 01- 28 
a infância no cinema de abbas kiarostami

face da situação dilemática. A frustração de ambos, no entanto, não é capaz de mobilizar os mais velhos.

Já o longa-metragem Os alunos do primeiro ano acompanha os dias iniciais de aula de uma turma (alunos de 6 anos, em média) na escola Tohid, em Teerã. O filme segue o dia a dia do diretor da escola, e suas cenas se dão, principalmente, em dois ambientes: no pátio, onde o diretor interage com a escola como um todo (recebendo os alunos, dando recados e cortando frutas para as crianças nos intervalos), e na sala do diretor, onde este atende indivíduos e pequenos grupos em situações típicas do cotidiano escolar (alunos que chegam atrasados na escola, outros que entram em conflito, pais que desejam matricular seus filhos e funcionários incomodados com o comportamento das crianças).

Ao abordar os primeiros dias de uma turma de primeiro ano, Kiarostami tematiza o ingresso na vida escolar. $\mathrm{O}$ trabalho de filmagem se deu in loco em uma escola regular, sem nunca esconder a câmera ou pedir para que as crianças não olhassem diretamente a ela, pois o diretor acreditava que assim as filmagens seriam mais espontâneas (KIAROSTAMI, 2013).

O filme dá destaque para os conflitos entre os alunos. A sala do diretor, onde se passa a maior parte do documentário, é palco para as mais variadas desavenças entre as crianças. $O$ diretor pune, quando necessário, bem como propõe soluções - em geral, um aperto de mão entre os envolvidos - para as contendas. Chama a atenção como os pequenos pouco falam em tais ocasiões. Após narrar o acontecido, o adulto intervém com uma sequência de perguntas de cunho retórico, as quais são respondidas com um murmúrio cabisbaixo. $\mathrm{O}$ diretor diz aos alunos o que devem falar e fazer para o outro; e estes o fazem. No filme, muitos dos conflitos envolvem a discussão sobre qual punição deve ser dada às crianças que cometeram determinada infração. Nesse sentido, é marcante a cena em que um garoto pede ao diretor que o perdoe, e este, por sua vez, responde: "O perdão não é uma punição".

Em uma das cenas de Os alunos do primeiro ano, um aluno é encaminhado à sala do diretor em razão de um conflito no qual se envolveu. $\mathrm{O}$ mais velho repreende 
o garoto apontando que aquela era a quinta vez que isso acontecia e que, por isso, iria suspendê-lo. A criança começa a chorar enquanto o mais velho faz perguntas sobre sua vida doméstica e o ofício de seus pais. Logo descobre que o garoto vive quase sem contato com seus pais, em razão dos horários de trabalho destes e as horas que passa na escola. Quando sai da escola, vai ao hospital onde a mãe trabalha como enfermeira para buscar as chaves de casa, e volta sozinho. Chegando em casa, janta a refeição que a mãe preparara previamente e vai dormir. No dia seguinte, levanta-se sozinho e vai à escola. Após entender o cotidiano do garoto, o diretor deixa de falar sobre suspensão e pede ao menino que diga a sua mãe que venha à escola conversar com ele.

Em Caso 1, Caso 2, Kiarostami apresenta uma cena hipotética segundo a qual, em uma sala de aula, um professor está escrevendo no quadro quando um aluno sentado ao fundo da sala começa a bater na mesa, causando um ruído incômodo. Ao se virar para eles, o barulho para, e o professor então volta a escrever. A cena se repete. Na terceira vez, sem conseguir identificar o autor, o docente se dirige a sete garotos sentados ao fundo e diz que estão todos suspensos por uma semana, a não ser que alguém diga quem estava atrapalhando a aula. Desenvolvem-se então os dois casos que dão título à obra: no primeiro, após três dias, um dos alunos retorna à sala e informa qual de seus colegas é o culpado; no segundo, eles permanecem os sete dias em silêncio. As duas situações são reapresentadas a diversas pessoas, que vão desde pais até lideranças religiosas e experts educacionais. Os entrevistados têm então de comentar e justificar se concordam ou discordam das ações.

Também inspirado em um episódio que um dos filhos de Kiarostami presenciou na escola, Caso 1, Caso 2 foi filmado originalmente no início de 1979 e estava quase pronto quando teve de ser interrompido por conta da Revolução. Seis meses após a interrupção, por conta da troca de regimes, Kiarostami decide refazer as filmagens, entrevistando integrantes do novo regime. O filme foi lançado no mesmo ano. A obra foi projetada no Primeiro Festival de Cinema Pós-Revolucionário de Filmes para Jovens, recebendo o prêmio mais importante do evento. 
a infância no cinema de abbas kiarostami

Pouco tempo depois, Khomeini pronunciou um discurso em que incitava a população a delatar infratores às autoridades. Alguns dos entrevistados no filme, que faziam parte do regime, diziam que a delação era um ato de traição condenado pelo Islã. O filme foi então censurado e sua exibição, proibida no Irã. A propósito disso, Kiarostami (2013, p. 251) comenta:

Talvez seja o filme mais proibido do Irã, porque os homens de Estado mudaram de rosto, dizendo inicialmente uma coisa para depois fazer completamente o contrário e, portanto, não querem ver essa transformação. Foi censurado enquanto documento de época, enterrado, mas existe. É um documento sobre a revolução e sobre as relações dos homens consigo próprios e com as regras sociais.

No filme, ao comentar a situação em que um professor faz um aluno delatar um de seus colegas, o entrevistado Nader Ebrahimi - escritor e diretor da Organização para a Cooperação com Crianças e Adolescentes - reconhece que um crime teria ocorrido ali, pois o professor submeteu seus alunos a uma situação de delação, convocando-os a trair os colegas; situação esta com a qual as crianças não sabem lidar, uma vez que os pais não lhes ensinaram como agir em situações como aquela.

Comentando o segundo caso, em que os alunos resistem às exigências do professor, Ebrahimi afirma:

$\mathrm{Eu}$ acredito que uma criança nunca pode ser considerada como um criminoso. Crimes são cometidos por adultos. Como em um hospital, um doente sempre tem a razão por conta de sua condição, a criança está sempre correta por conta de sua condição. [...] Essa ação dos alunos de resistência merece uma alta credibilidade social e política, ela pode servir de modelo revolucionário para as outras crianças, pode prepará-las para a construção da nação no futuro.

O depoimento de Ebrahimi elucida duas questões relevantes. Primeiro, ao entender o professor e os pais como responsáveis pela delação - em sua concepção, algo negativo -, isenta os mais novos de qualquer responsabilidade sobre seus próprios atos, atribuindo-lhes certa incapacidade de julgar. A expressão máxima de tal ideia é a analogia que faz entre um doente e uma criança, já que ambos não poderiam ser responsabilizados por sua condição. Segundo ponto: em face da resistência dos alunos que se recusam a delatar o colega, o entrevistado identifica-os como merecedores de louvor, um exemplo importante para a construção da nação 16 childhood E philosophy, rio de janeiro, v. 15, jan. 2019, pp. 01 - 28

issn 1984-5987 
futura. Tais ideias operam um movimento paradoxal: por um lado, a criança como um ser irresponsável, secundário e lateral ante os acontecimentos; por outro, ela como protagonista do futuro, responsável pelos rumos do país.

\section{2. a criança no centro da sociedade}

A ideia de Lição de Casa teria surgido de um problema que Kiarostami teve enquanto ajudava o filho com seus deveres escolares. O diretor afirma que estes são direcionados às crianças, mas muitas vezes os adultos acabam envolvidos. Curioso para saber se outras pessoas tinham problemas semelhantes, ele decide entrevistar integrantes da comunidade escolar. A obra segue com as gravações sempre em uma pequena sala, no formato de entrevistas. Três planos de filmagem são empregados: o do entrevistado, o do entrevistador e aquele que mostra a câmera de filmagem junto ao operador. Os entrevistados são, em sua maioria, crianças, à exceção de alguns pais.

As perguntas exploram a dificuldade das crianças em fazer os deveres, que muitas vezes consistiam em ditados que precisavam ser realizados por outrem para que os alunos pudessem reproduzi-los. No entanto, muitas vezes os responsáveis estavam trabalhando ou eram analfabetos e, por isso, não conseguiam ler para os pequenos, os quais, por sua vez, deixavam de cumprir as obrigações escolares. Também é abordado o tema dos castigos aplicados aos alunos que não correspondiam à expectativa escolar.

Tendo levado a cabo as filmagens na escola de seu filho, Kiarostami reputa essa obra como algo destoante do resto de sua filmografia, por não ser um filme convencional, mas o relato de uma pesquisa pessoal, isto é, um estudo por imagens.

A falta de escuta dos mais velhos é, novamente, um dos temas de Lição de Casa. Nas entrevistas, muitas das crianças têm de responder se compreendem o significado da palavra punição. Quase todas afirmam que se trata de levar surra, e algumas descrevem ocasiões nas quais sofreram algum castigo físico dos professores ou dos pais. Quando perguntados sobre o que é prêmio, ou incentivo, não sabem responder. 
a infância no cinema de abbas kiarostami

A respeito do filme, Kiarostami (2013, p. 225) declara:

Sem recriar nenhuma cena, mas fazendo apenas certas perguntas simples consegui mostrar o modo como as crianças estudam, as relações com os pais, se estes ajudam ou não. É verdade: trata-se de um filme composto apenas por uma série de entrevistas, mas, se não estivermos habituados a observar o rosto das crianças, não conseguimos perceber o tema. Sem esse olhar por parte do espectador, nenhum tipo de cinema no mundo é suficiente para descrever a solidão e a beleza do homem.

Na sequência, o diretor afirma que o filme teve um impacto positivo sobre a sociedade iraniana, expondo como o país e seu sistema educacional "não se preocupam com os problemas da infância como deveriam" (KIAROSTAMI, 2013, p. 226). Segundo ele, muitos professores e pais admitiram ter alterado seu comportamento após verem o filme, e mesmo ele diz ter conhecido melhor seus filhos após a experiência.

Em determinado momento do filme, Kiarostami recebe um pai que informa que seu filho não está matriculado na escola, mas que veio tratar da possibilidade de uma transferência. O homem, ao saber das gravações, pede para participar, discutindo a educação iraniana diante das câmeras. Relata que morou em outros países, como Canadá e Estados Unidos, e que observou seus respectivos sistemas educacionais. Muitos países, segundo o entrevistado, não exigiam lição de casa nas escolas e, quando o faziam, enfocavam principalmente a criatividade da criança, por meio de desenhos e construções. Como contraponto, cita o Japão, país que possuía um sistema educacional tradicional e rigoroso, mas que, em virtude das elevadas taxas de suicídio infantil, estava sendo obrigado a rever suas diretrizes.

O pai segue seu argumento dizendo que, nas escolas iranianas, as crianças estavam constantemente sob uma carga muito elevada de pressão, sendo cobradas para atingir um nível de excelência em todas as matérias, além de estarem expostas a uma carga excessiva de deveres de casa. Afirma ainda que, da forma como as coisas estavam dispostas, a tensão sobre as crianças acarretaria graves problemas psicológicos, fazendo com que acabassem privadas de qualquer possibilidade de criatividade. O entrevistado caracteriza o sistema educacional de seu país como medieval. Para ele, seria preciso caminhar em direção ao século $X X$ e que os 
professores pensassem diferente, respeitando as capacidades de seus alunos. Para tanto, as crianças não deveriam ser forçadas a fazer a lição de casa, de modo que os pais não tivessem de se tornar professores particulares, dando cabo dos incessantes trabalhos escolares.

$\mathrm{O}$ argumento de que as aulas deveriam levar em consideração o envolvimento dos alunos também aparece em Caso 1, Caso 2, quando o Bispo Ardok Manoukian, líder religioso da comunidade armênia do Irã, diz que o professor, ao se demorar no quadro, deixou os alunos entediados e, por isso, não conseguiu se conectar com a turma. Logo, se um aluno causasse algum distúrbio em sala, o responsável seria o professor, já que não teria conseguido ministrar uma aula interessante. Ezzatollah Entezami, artista cênico que também aparece no filme, apresenta uma crítica semelhante, dizendo que as aulas deveriam ser envolventes e que não se poderia cobrar dos discentes que permanecessem quietos enquanto o professor escrevesse na lousa. Por sua vez, o Ayatolah Sadegh Khalkhali, membro do Magistrado Religioso da Corte Revolucionária, critica o educador por considerar que este deveria se aproximar do problema de maneira a valorizar a alma da criança, valendo-se da compaixão.

Somados os depoimentos, atesta-se um movimento que posiciona a criança no centro do meio educativo: um ser que deve ser considerado o fulcro das práticas escolares. Exemplo disso é Duas soluções para um problema.

No filme, um narrador apresenta dois colegas de classe, Nader e Dara, que são amigos. Após receber um livro que havia emprestado a Dara, Nader percebe que sua capa estava rasgada. Frustrado, o menino pega uma brochura de seu colega e o rasga; o outro, por sua vez, pega a caneta do amigo e a quebra em duas partes. O ciclo de retaliações segue até atingir o ápice, quando os dois se engajam em um confronto físico. O narrador então resume o episódio, exibindo em uma lousa uma tabela com o saldo do confronto: Dara teve seu livro, sua bolsa e sua camisa rasgados, seu chapéu sujo e um olho roxo. A brochura de Nader foi rasgado, sua caneta e sua régua quebradas, seu cachecol sujo, além da testa machucada. Desenvolve-se, então, um 
a infância no cinema de abbas kiarostami

segundo caso: ao perceber que a capa fora rasgada, Nader mostra ao amigo, que, por sua vez, com auxílio de uma cola, repara o malfeito. O conflito se encerra e o narrador resume o acontecimento, enunciando que o livro foi consertado e que os dois ainda são amigos.

Kiarostami reputa Duas soluções para um problema como seu primeiro filme de cunho estritamente pedagógico, expondo um problema e duas soluções possíveis. Na primeira configuração, que pouco parece uma solução, uma sequência de sucessivas retaliações ganha corpo, gerando uma série de atos que rompe a amizade dos dois alunos envolvidos, sem alterar o problema original: o caderno rasgado. Na segunda situação, a narrativa apresenta uma alternativa pacífica, segundo a qual os alunos cooperam e, juntos, reparam o dano; assim, a amizade se mantém conservada, e o problema é resolvido. O filme evoca, portanto, a colaboração e a união entre as crianças.

Voltando a Caso 1, Caso 2, Iraj Jahanshahi, apresentado como um expert educacional, condena a ação do garoto no primeiro caso, em que o aluno delata o colega que estava causando o problema, dizendo que não se deveria trair o grupo, uma vez que os homens sobrevivem como coletividade. Ebrahim Yazdi, Ministro de Relações Exteriores, valoriza o mesmo aspecto, criticando os valores em voga em seu país, ao tomá-los como algo que afastaria as pessoas da coletividade em direção à individualidade. Noureddin Kianouri, Secretário Geral do Comitê Central do Tudeh, ${ }^{3}$ comentando o caso em que acontece a traição, afirma que o menino deveria ter consultado seus colegas antes de agir, para que eles pudessem chegar a uma solução conjunta; ao agir independentemente, teria de enfrentar o ódio dos colegas.

Os entrevistados Karim Zarrineh, pai de um dos atores, e Kamal Kharrazi, diretor executivo do Kanun, também evocam a importância de os jovens se manterem unidos e preservarem o sentimento mútuo de solidariedade. $\mathrm{O}$ ator Ezzatollah Entezami ressalta a importância de se preservar o coletivo, condenando qualquer ato de traição por parte de um indivíduo. Em suma, os argumentos expostos pelos

\footnotetext{
${ }^{3} \mathrm{O}$ partido comunista iraniano.
}

20 childhood E philosophy, rio de janeiro, v. 15, jan. 2019, pp. 01 - 28 
entrevistados trazem à baila um novo elemento: a importância da cooperação e união entre as crianças, agora alçadas à condição de centro da sociedade.

\section{3. a criança da revolução}

Em determinada cena de Os alunos do primeiro ano, dois garotos - Mahammad Mahmudi e Abbas Nikmalek - são levados para a sala do diretor. O primeiro torceu o braço do segundo, que, em resposta, empurrou o outro. Ao ser empurrado, Mahmudi cai no chão e bate a cabeça. $\mathrm{O}$ diretor, ouvindo o relato dos garotos, indaga o que fazer para resolver a desavença. Ironicamente, pergunta se a solução seria que o último agredido retribuísse a violência. Mahmudi diz que perdoa o colega, enquanto o outro permanece em silêncio. O diretor insiste: "Apesar das coisas ruins que ele fez para você, você o perdoa?". O garoto consente, mas Nikmalek permanece em silêncio. O diretor se incomoda com a mudez do garoto e ordena que ele espere do lado de fora, uma vez que parece não estar arrependido de seus atos. Uma câmera no corredor, do lado de fora da sala do diretor, mostra os dois garotos se retirando. Mahmudi retorna à sala de aula, e Nikmalek permanece ao lado da porta da direção. O primeiro para no meio do caminho e volta para falar com o diretor. Após uma breve conversa, o mais velho pede para que os três retomem a conversa.

Mahmudi pede encarecidamente ao diretor que deixe seu colega voltar à sala de aula. O diretor, por sua vez, diz não haver motivo para fazê-lo. O pequeno, aos prantos, implora que deixe seu amigo voltar. $\mathrm{O}$ diretor insiste que, apesar de ter sido perdoado, Nikmalek - que durante todo o diálogo permaneceu em silêncio - não mostra nenhum sinal de arrependimento; por isso, acredita que o menino não aprendeu a lição. $\mathrm{O}$ adulto volta-se ao aluno silencioso e profere:

Você vê o quanto ele se importa com você? Ele chora e defende você. Vê quão bom ele é? Você, no entanto, não mostra nem um pouco de remorso. Nem sequer disse que estava arrependido. Fica aí e olha para mim. Olhe para ele, está chorando porque você vai perder a lição. Ele não quer que você fique para trás, está implorando para que eu deixe você ir [...] e você permanece calado. Talvez não tenha notado que o empurrou? Você fez isso de propósito? 
a infância no cinema de abbas kiarostami

Pela primeira vez, Nikmalek se pronuncia, afirmando que não agiu propositalmente. O diretor esclarece que essa é a razão por trás da falta de remorso do menino, pois ele não agrediu seu colega intencionalmente. Agora as duas crianças estão a chorar. A autoridade pede aos dois que apertem as mãos e deem um beijo um no outro. Os pequenos assim o fazem e deixam a sala de mãos dadas.

O gesto de solidariedade de Mahmudi transforma o que antes era um conflito entre alunos em um enfrentamento de ambos os dois com o diretor. Aqui, algo análogo a Caso 1, Caso 2 parece se repetir. Sobre o ato de resistência dos alunos neste último filme, ao decidirem não denunciar ninguém, Sadeegh Ghotbzadeh, diretor de rádio e televisão, comenta:

No geral, solidariedade e ação coletiva devem ser valorizadas, mas o problema aqui é a educação. $\mathrm{O}$ valor da solidariedade deveria ser avaliado em seu contexto: solidariedade com crime, assassinato e vícios é tão valiosa como a com atos bons, ações revolucionárias e resistência contra a opressão?

Em relação ao mesmo episódio, o advogado, membro do Comitê Executivo da Frente Democrática, Hedayatulah Matindaftari, aponta como a ação dos garotos, ao resistirem à autoridade e preservarem a integridade do coletivo, foi correta, e que depois, entre iguais, eles deveriam decidir o que fazer em relação ao garoto que estava causando problemas. Em uma linha argumentativa semelhante, o pai de um dos atores (da cena de Caso 1, Caso 2) diz:

Meu filho se comportou bem, o sujeito aprende sobre solidariedade da infância em diante. Quando essas crianças crescerem vão estar preparadas para qualquer problema. Se ele contar quem foi, pode até ser presenteado pelo professor, mas quando crescer não vai passar de um delator, um dedoduro. Ao resistir ele mantém a sua integridade e, portanto, mais tarde vai ser respeitado quando pedir aos seus colegas que não atrapalhem a aula.

Como já apontado anteriormente, Onde fica a casa do meu amigo? é marcado pela dificuldade de comunicação entre o protagonista e os adultos de seu entorno. Cabe aqui recuperar a última cena do filme. Nela, vemos as crianças sentadas na sala de aula, mas o protagonista Ahmad (aquele que deveria devolver o caderno do amigo) está ausente. O professor entra e cumprimenta todos. Um dos alunos avisa que seu colega não veio, ao que o professor reafirma que os alunos não deveriam falar nada, a não ser quando fossem questionados. 
Na sequência, o professor pede para ver as lições de casa e os alunos colocam seus cadernos sobre a mesa para que ele verifique um a um. Um close em Nematzadeh revela uma expressão angustiada. Vale lembrar que, no dia anterior, o professor havia advertido que, se ele não trouxesse a lição no caderno mais uma vez, seria expulso.

O professor continua a corrigir os deveres de casa, se aproximando cada vez mais do momento de Nematzadeh mostrar seu caderno. A porta da sala se abre, chega Ahmad. O professor o repreende pelo atraso, mas o deixa entrar. Ele dirige-se ao seu lugar, ao lado do colega que estava sem o caderno. Ahmad devolve a brochura ao amigo e revela que havia passado a noite anterior fazendo sua lição e a do amigo. O professor chega, olha o caderno dos meninos individualmente e, sem detectar a falsificação, parabeniza-o, seguindo para a correção do próximo caderno. Assim o filme se encerra. Em um gesto subversivo, o pequeno Ahmad consegue fraudar o dever em favor de seu amigo, ludibriando o professor e, assim, evitando que ele fosse punido.

Retornando a Caso 1, Caso 2, a diretora de assuntos educacionais do Instituto para o Treinamento e Aperfeiçoamento da Crianças e do Adolescentes, Jaleh Sarshar, assim se manifestou acerca da ação de resistência dos jovens:

Eu concordo com a ação dos meninos, essa é a melhor forma de resistir a um inimigo em comum. [...] Mesmo que a solidariedade e ações deles ajam contra o nosso trabalho e mesmo que tenhamos que intervir, por mais que eu nunca apoiaria uma intervenção destas, podemos utilizar os exemplos desta unidade para os nossos programas educacionais.

Por sua vez, o líder da comunidade judaica do Irã, Rob David Shoft, comentou:

$\mathrm{Na}$ minha opinião, essa ação não foi correta, não a vejo como uma solidariedade ou resistência positiva. Em um contexto político é diferente, mas em um contexto educacional, onde aconteceu esse evento, honestidade deveria ser o maior valor. Portanto, essa reação não é adequada.

Nos dois pronunciamentos, a resistência e a solidariedade são consideradas valores fundamentais. No entanto, os depoentes discordam quanto a se tratar de ações válidas, a depender do contexto ou do sentido que persigam. 
a infância no cinema de abbas kiarostami

Ainda julgando os acontecimentos de Caso 1, Caso2, o diretor executivo do Kanun, Kamal Kharrazi, entende que a resistência dos alunos foi correta, uma vez que ela se deu em reação a uma fraqueza do professor. O então ministro da educação do Irã, Gholam Hossein Shokouhi, defende argumento semelhante, entendendo que o professor é o responsável por gerar uma situação desagradável, e que a resistência dos garotos teria sido uma resposta apropriada. O escritor e poeta, Ali Mousavi Garmaroudi, também atribui culpa ao professor, e ainda exalta a resistência dos alunos como um ato que comprova a vivacidade deles.

O diretor do Departamento de Publicações do Kanun, Gholam Reza Emami, entende que a resistência por si só pode ser considerada um ato sagrado; no entanto, no caso dos garotos que se recusam a delatar o colega que estava atrapalhando a aula, ela se deu em nome de um objetivo incorreto. Apontando que, uma vez que a sala é composta por muitos alunos além dos sete que foram suspensos, o sujeito que atrapalhou a aula atentou contra a liberdade do grupo como um todo, e que não é correto proteger um indivíduo que agiu contra o coletivo. Já Abdolkarim Lahiji, advogado e vice-presidente do Comitê por Direitos Humanos e Defesa da Liberdade do Irã, destaca a resistência como um ato sagrado e glorioso, independentemente das razões que a incitaram. Ele ainda opera uma analogia segundo a qual a situação de delação convocada pelo professor é tida como como um reflexo da cultura imunda de traição instaurada pelo Xá, a qual teria se disseminado principalmente com a criação da Savak ${ }^{4}$ em 1957.

Ebrahim Yazdi, Ministro das Relações Exteriores do Irã na época em que ocorreram as filmagens, também propõe uma comparação entre a situação ocorrida e os valores culturais em seu país. Entendendo que o professor, ao punir os alunos, condenou um grupo sem qualquer tipo de investigação, baseando-se apenas em conjectura e suposição, ele teria agido de forma análoga ao modo de governo do Xá. Assim, a reação de resistência dos alunos só poderia ser vista como algo natural.

4 Polícia secreta e serviço de inteligência do regime do Xá, dissolvida após a revolução em 1979.

24 childhood E philosophy, rio de janeiro, v. 15, jan. 2019, pp. 01 - 28

issn 1984-5987 
Por fim, o Hojjatoleslam, ${ }^{5}$ Ali Golzadeh Ghafouri, membro da Assembleia dos Experts, ${ }^{6}$ também oferece uma analogia entre a resistência dos alunos e a situação política do país, sem, no entanto, aprovar a ação dos alunos.

Nós vemos estes sujeitos como crianças, mas na verdade elas representam todo um mundo de humanidade. Minha questão é: por que elas [as crianças] voltaram para a sala e não tentaram mudar o sistema como um todo? Voltaram às mesmas carteiras, colegas e professor. Acredito que a resistência delas seja boa, mas elas não deveriam simplesmente voltar ao sistema antigo.

Aqui, condena-se a ação dos alunos não pela resistência contra o professor, mas, curiosamente, pela falta de radicalidade desses artífices desavisados da revolução.

\section{considerações finais}

Retomando retrospectivamente o percurso argumentativo do presente estudo, traçaram-se três movimentos articulados nas obras cinematográficas de Abbas Kiarostami, a reboque dos quais os modos de relação entre os mais novos e destes com a sociedade constituem um foco argumentativo recorrente.

Em primeiro lugar, deve-se destacar o fato de que os seis filmes tratados apresentam uma infância assolada por angústias de diferentes ordens. Os pequenos devem escutar e respeitar os mais velhos, obedecer seus professores e também seus pais, mesmo que estes se contradigam. Quando desobedecem, devem ser punidos; a punição, claro está, é parte essencial da educação ali retratada. Por outro lado, as crianças também devem ser solidárias, se preocupar com seus colegas, prezando o diálogo e o respeito mútuo, sem jamais agir contra o coletivo ou cometer qualquer tipo de traição. É o que pontificam os mais velhos, mas as crianças já parecem sabê-lo bem. Mediante um mundo que as abandona e reprime, elas estabelecem suas alianças, protegem umas às outras, defendem-se das punições impostas pelos adultos e, no limite, enfrentam as autoridades em defesa de seus colegas.

5 Título de autoridade no Islã.

${ }^{6}$ Grupo de representantes, eleitos por votação popular, responsável pela elaboração da Constituição Nacional após a Revolução de 1979. 
a infância no cinema de abbas kiarostami

Em um país marcado por uma insurreição popular inspirada em valores de uma religião cujo significado maior advém do ato de se submeter, ${ }^{7}$ o que esperar dos mais novos? Que fiquem quietos e obedeçam. No entanto, quando se levantam contra as exigências injustas de um professor, são celebrados como exemplos para a nação. Seria a sublevação infantil um paradigma subjetivo para o novo regime que se instaurava? Ou o reflexo de um povo que já resistia às novas autoridades? O embate geracional característico do trabalho educacional mimetizaria, assim, a luta de um povo engajado em um levante em busca de justiça social. Em suma, a transfiguração do cidadão corrompido da sociedade do Xá em um novo sujeito, este tido como peça fundamental da refundação societária que ali se especulava. É no rastro de tal mote que a obra de Kiarostami sobre a infância poderia, em princípio, ser contextualizada. Mas não apenas isso.

Pressupondo que os filmes dirigidos por Kiarostami portariam algum propósito educativo, faz-se necessário ter em vista a quem eles se endereçavam. Quem teria algo a aprender com aqueles retratos singulares da infância? Tratava-se de uma denúncia direcionada aos mais velhos sobre as agruras dos infantes? Ou de lições sobre solidariedade e companheirismo como mensagens edificantes dirigidas também aos mais velhos?

Caso 1, Caso 2 - o filme mais revisitado em nosso percurso - é icônico nesse sentido. Ali, são as próprias autoridades que avaliam os sentidos do ato de resistir. Trata-se de um debate que considera mais os sentidos éticos da união e da resistência do que as angústias pessoais dos protagonistas. Vale lembrar que o filme foi gravado e lançado em 1979, tendo sido premiado e, poucos meses depois, proibido no país. Sobre a obra, Kiarostami (2013, p. 215) afirma: “É um dos raros filmes sociais, se assim se pode dizer, que nos faz pensar o sistema moderno, que nos impôs outro estilo de vida e fez de nós seres inumanos. [...] É um documento sobre a revolução e sobre as relações dos homens consigo próprios e com as regras sociais". O pronunciamento do diretor evidencia um princípio de ação digno de nota: por meio

7 A Encyclopedia of The Qur'ān apresenta no verbete Islã a seguinte definição: "The infinitive of the fourth form of the triliteral root S-L-M meaning 'to submit, 'to surrender'" (ARKOUN, 2002, p. 565).

26 childhood E philosophy, rio de janeiro, v. 15, jan. 2019, pp. 01 - 28

issn 1984-5987 
da focalização da infância, tratava-se de pôr em causa os impasses sociais vividos naquele momento histórico específico.

Desta feita, a obra de Kiarostami apresenta-se como uma força imagética capaz de simultaneamente descrever e produzir certa perspectivação da realidade, ou seja, uma força voltada à (re)constituição dos torneios veridictivos em voga. Nesse sentido, compreende-se que os filmes do diretor iraniano são, também eles próprios, um vetor interveniente nos processos de veridicção/subjetivação ali atuantes. Isso significa que certa perscrutação acerca dos modos de pensar/ser sujeito naquela sociedade que a Revolução instaurara é performada em e por tais filmes, sempre a partir dos dilemas éticos das crianças sobre como agir em relação aos adultos e/ou entre si.

O cinema sobre a infância de Kiarostami finda por se apresentar, quer-nos parecer, como um ponto de inflexão das modalidades veridictivo-subjetivadoras ali correntes - fossem elas revolucionárias, tradicionalistas ou, no mais das vezes, ambas -, tratando-se justamente do cinema como suporte fático de um gesto ético-político. Ético na medida em que aborda as inflexões da vida privada que dizem respeito às sempre difíceis escolhas do sujeito; daí, a infância como espaço germinal de subjetivação. Político na medida em que dá a ver os meandros da vida pública, ou seja, os modos triviais de agir para com o próximo e a sociedade; daí, o ensejo fílmico de recompor determinada realidade em ebulição.

Se tal prospecção for plausível, restar-nos-á admitir que as obras de Kiarostami sobre a infância iraniana na ambiência pré e pós-revolucionária consistem em um tipo peculiar de exercício estético. Com efeito, os filmes aqui revisitados operam, a nosso ver, à moda de um campo de experimentação narrativa que se vale dos usos e costumes infantis como ocasião de prospecção daquilo que estava em curso em pleno processo revolucionário e, no limite, do ideário que as autoridades pretendiam implementar. Em suma, os pequenos, por um lado, como depositários de expectativas superestimadas, e, por outro, como portadores de respostas sempre insuspeitas. 
a infância no cinema de abbas kiarostami

\section{referências}

ARKOUN, M. Islam. In: McAULIFFE, Jane Dammen. Encyclopaedia of the Qur' ān: volume two E-I. Boston: Brill, 2002.

BERNARDET, Jean-Claude. Caminhos de Kiarostami. São Paulo: Companhia das Letras, 2004. COGGIOLA, Osvaldo. A revolução iraniana. São Paulo: Editora Unesp, 2008.

DIDI-HUBERMAN, Georges. Quando as imagens tocam o real. Pós, Belo Horizonte, v. 2, n. 4, p. 204-219, 2012.

DIDI-HUBERMAN, Georges. Cascas. Serrote, São Paulo, n. 13, p. 99-133, mar. 2013.

ERIBON, Didier. Michel Foucault, 1926-1984. São Paulo: Companhia das Letras, 1990.

FABRIS, Elí Henn. Cinema e educação: um caminho metodológico. Educação e Realidade, Porto Alegre, v. 33, n. 1, p. 117-133, jan./jun. 2008.

FOUCAULT, Michel. História da Sexualidade II: o uso dos prazeres. Rio de Janeiro, Graal, 1984. FOUCAULT, Michel. Com o que sonham os iranianos? In: . Repensar a política. Rio de Janeiro: Forense Universitária, 2013a. p. 230-236.

FOUCAULT, Michel. O espírito de um mundo sem espírito. In: . Repensar a política. Rio de Janeiro: Forense Universitária, 2013b. p. 258-270.

FOUCAULT, Michel. O nascimento de um mundo. Em Filosofia, diagnóstico do presente e verdade. Rio de Janeiro: Forense Universitária, 2014. p. 51-54.

KIAROSTAMI, Abbas. Abbas Kiarostami. São Paulo: Cosac Naify, 2013.

MARCELLO, Fabiana de Amorim; FISCHER, Rosa Maria Bueno. Tópicos para pensar a pesquisa em cinema e educação. Educação e Realidade, Porto Alegre, v. 36, n. 2, p. 505-519, maio/ago. 2011.

MELEIRO, Alessandra. O novo cinema iraniano: arte e intervenção social. São Paulo: Escrituras, 2006.

TAPPER, Richard. (Org.). The new iranian cinema: Politics, representation and identity. Londres e Nova York: I. B. Tauris Publishers, 2002.

recebido em: 26.08 .2018

aprovado em: 02.11 .2018 